\title{
Problematika Pengembangan Praktik Jurnalisme Lembaga Penyiaran Publik
}

\author{
Anang Hermawan \\ Program Studi Ilmu Komunikasi Universitas Islam Indonesia
}

Abstrak

Tulisan ini berusaha mengelaborasi dinamika dan problematika praktik jurnalistik pada salah satu lembaga penyiaran publik, yakni LPP RRI. Isi telaah didasarkan pada beberapa studi yang penulis lakukan di beberapa stasiun RRI, antara lain di wilayah meliputi Gorontalo, Manokwari, Batam, dan Makassar; termasuk pula beberapa studi serupa oleh Tim Peneliti RRI di kota lain pada tahun 2011-2012. Secara umum, pengakuan eksistensi Lembaga Penyiaran Publik sejak satu dekade silam belum diikuti oleh praktik penyiaran yang independen dan memberi layanan informasi yang optimum untuk masyarakat. Pada tingkat praksis jurnalistik, sekalipun kehadirannya pada kawasan terpencil dan perbatasan siaran RRI masih diminati, praktik jurnalisme penyiaran di kedua lembaga tersebut pada umumnya masih belum mampu menjadi pilihan publik. Permasalahan yang dihadapi berkisar pada rendahnya kualitas implementasi manajemen redaksional, termasuk di dalamnya ketersediaan sumber daya yang memadai; perhatian terhadap infrastruktur, serta pengarusutamaan siaran jurnalistik RRI untuk menjadikannya sebagai institusi pers dan penyiaran yang independen. Sebagai karya hasil observasi dan dokumentasi lapangan, tulisan ini tidak berpretensi melakukan kajian dokumentatif terhadap kinerja karya jurnalistik pada siaran-siaran berita yang dihasilkan oleh radio-radio yang dikaji, melainkan lebih pada problematika kelembagaan dan persoalan lapangan dalam konteks pelaksanaan praktik jurnalisme penyiaran di RRI.

Kata Kunci: Jurnalisme penyiaran, lembaga penyiaran publik, radio, Radio Republik Indonesia

\section{Pendahuluan}

Memasuki dekade pertama Lembaga Penyiaran Publik (LPP), Radio Republik Indonesia (RRI) dan Televisi Republik Indonesia (TVRI) telah berupaya melakukan aneka pembenahan. Di tengah memuncaknya perhatian publik terhadap penyiaran swasta, masih tersisa perhatian negara kepada kedua lembaga tersebut untuk mewujudkan dirinya sebagai lembaga penyiaran publik. Tertumpu harapan agar keduanya mampu menjadi kekuatan penyeimbang bagi terselenggaranya sistem penyiaran yang mencerminkan semangat keberagaman kepemilikan antara swasta, publik, dan komunitas. Lahirnya undang-undang dan regulasi pemerintah yang menjamin ketiga unsur kepemilikan tersebut tentu patut diapresiasi. Namun demikian, dalam praktiknya kepemilikan swasta masih mendominasi, sehingga dua kekuatan pendampingnya: penyiaran publik dan penyiaran komunitas masih kalah bersaing merebut perhatian publik.

Di lingkungan RRI, langkah pembenahan pertama dijalankan melalui perubahan visi yakni "Mewrjudkan LPP 
RRI sebagai radio berjaringan terluas, pembangun karakter bangsa, berkelas dunia." Melalui perubahan visi tersebut, dilanjutkan dengan pembenahan berikutnya berupa klasifikasi ulang terhadap satuan penyelenggara siaran menjadi lima programa: Pro1, Pro2, Pro3, Pro4, dan Siaran Luar Negeri yang masing-masing mencerminkan karakter program siaran beserta khalayak yang dituju. Istilah 'programa' yang selama ini menjadi dalam yang menjadi ciri khas RRI masih dipertahankan. Meski agak membingungkan secara akademis, karena umumnya istilah tersebut berarti sebagai program siaran; RRI membuat definisi tersendiri yang nampaknya memang hanya berlaku di lingkungan internal, yakni "saluran penyelenggaraan siaran dari stasiun RRI sesuai dengan karakteristik dan segmen pendengar yang dituju" (Pedoman Penyelenggaraan Siaran RRI Pro1 dan Pro2, 2011).

Format siaran Pro1 ditujukan untuk pemberdayaan masyarakat lokal (local community), Pro2 untuk menjadi pusat pengembangan kalangan muda (youth), Pro3 sebagai wahana jaringan berita nasional, dan Pro4 dirancang sebagai saluran penyelenggara siaran kebudayaan. Dari keseluruhan stasiun radio yang ada, keempat saluran penyelenggara tersebut memang tidak seluruhnya diberi kewenangan untuk menyiarkan seluruh programa. Stasiun tipe A dan B diberi kewenangan menyiarkan keseluruhan programa, sehingga tipe $\mathrm{C}$ tidak berkewajiban menyiarkan siaran Pro4 (siaran kebudayaan). Selebihnya untuk menunjang keberadaan LPP yang bertugas melayani informasi, pendidikan, hiburan di seluruh wilayah Indonesia, RRI mendirikan Stasiun Produksi (SP) di kawasan terpencil dan wilayah perbatasan. Dengan jumlah keseluruhan yang tidak kurang dari 87 stasiun di seluruh wilayah Indonesia, keberadaan RRI memang diharap secara khusus untuk menjadi jaring pengaman kedaulatan nasional di bidang informasi yang terkristal dalam kredo "safety belt information" atau sabuk pengaman informasi. Terkait dengan program siaran berita, selain Pro3 yang secara khusus diperuntukkan untuk program jaringan berita skala nasional, masing-masing stasiun berkewenangan mengembangkan program-program beritanya di daerah masing-masing sesuai dengan kondisi dan karakter masyarakat setempat.

Di banyak daerah yang telah maju, pergeseran pola konsumsi media di lingkungan masyarakat tak urung menggeser peranan radio sebagai media informasi utama. Pada kawasan urban, di mana tingkat persaingan radio sangat tinggi, harus diakui bahwa pola kependengaran siaran RRI sekarang ini cenderung lebih rendah dibandingkan dengan di masa lampau. Tumbuh kembangnya penyiaran swasta, termasuk televisi telah mengubah pola konsumsi media. Bahkan di lingkungan masyarakat generasi muda, akibat penetrasi media baru, tingkat kependengaran terhadap RRI terbilang rendah. Lain halnya di daerah terpencil dan di kawasan perbatasan, di mana penetrasi siaran swasta relatif sedikit, siaran RRI masih cukup diminati.

Melekat di dalam fungsinya sebagai pemberi layanan pendidikan dan hiburan bagi seluruh pendengarnya, LPP RRI mewujud sebagai institusi pers yang bertugas memberi layanan informasi. Pada aras ini, dituntut kemandirian untuk menjadikannya sebagai institusi yang netral dan independen. Meski dibiayai oleh APBN, namun prinsip dasar radio publik selayaknya mencerminkan kepentingan publik. Transformasi inilah yang kemudian tidak mudah dijalankan, mengingat imaji RRI sebagai lembaga penyiaran milik pemerintah telah melakat kuat. Citra bahwa institusi RRI adalah corong pemerintah acapkali mengganggu 
jalannya proses transformasi menuju saluran publik yang ideal, yang notabene hanya mengatasnamakan kepentingan publik dalam setiap aktivitasnya. Selain itu, hegemoni kekuasaan yang telah melingkungi institusi ini selama rezim terdahulu telah membuat kultur dan etos kerja menjadi rendah sebagaimana terciri pada pola-pola kerja birokratis dan kurangnya kreativitas akibat terbiasa bekerja dalam lingkungan yang tidak kompetitif. Fakta historis demikian sangat mempengaruhi proses transformasi RRI menjadi radio publik yang ideal.

$\mathrm{Di}$ tengah situasi kekinian persaingan pers, posisioning RRI selaku media massa menghadapi situasi sulit karena secara faktual mesti berhadapan dengan kekuatan media massa lain. Dalam konteks sebagai media massa, RRI menghadapi kompetisi yang sangat ketat dengan media massa konvensional (radio, tv, surat kabar) maupun media baru (new media). Meskipun berbeda visi dan misinya dengan radio siaran swasta dan komunitas, tetapi dalam konteks memerebutkan perhatian "khalayak," ketiganya harus adu program dan mengoptimalkan daya tarik masingmasing. Begitu juga terhadap siaran televisi, surat kabar, majalah, dan media on line, RRI juga harus berusaha menarik. perhatian khalayak dari serbuan media lain tersebut agar siarannya mencapai sasaran. Ini karena betapapun bagus atau berkualitasnya isi siaran dan bervariasinya penyajian acara, tetapi kalau tidak didengarkan oleh khalayak juga tidak akan efektif.

\section{Kerangka Pemikiran dan Metode}

Sebagai · lembaga mediasi kepentingan publik, penyiaran radio memiliki fungsi strategis karena informasi yang disampaikannya mempunyai makna sosial. Makna sosial yang timbul bukan hanya disebabkan oleh sifat dasar komunikasinya yang sekadar informasional, melainkan juga dapat berarti instruksional, persuasif, maupun hanya sekadar menghibur masyarakat. Setiap realitas yang direpresentasikan oleh pers baik realitas psikologis maupun realitas sosiologis berpeluang melestarikan atau bahkan "memaksakan" norma sosial tertentu. Sebagaimana disitir oleh Siregar (1993), De Fleur yang menyatakan bahwa media dapat mengukuhkan norma-norma budaya dengan informasi-informasi yang disampaikan setiap hari. Selain itu mass media dapat mengaktifkan perilakuperilaku tertentu, apabila informasi yang disampaikannya sesuai dengan kebutuhan individu serta tidak bertentangan dengan norma budaya yang berlaku. Mass media bahkan dapat menumbuhkan norma budaya dalam perilaku selama norma tersebut tidak dihalangi oleh hambatanhambatan sosial budaya.

Kedudukan radio, sebagai bagian dari media massa pada umumnya lebih jauh dapat dilihat dari fungsinya dalam masyarakat sebagai pemelihara stabilitas dan harmoni sosial. Dengan fungsi semacam radio menjadi bagian dari mekanisme sosial yang menghendaki keseimbangan antar berbagi komponen dalam mayarakat. Dalam praktik kerjanya, di antara anasir penting keterlibatan wartawan/jurnalis, karena dari merekalah berbagai macam informasi dapat disebarluaskan. Dalam konteks inilah maka kajian terhadap pekerjaan wartawan menjadi penting karena pada dasarnya perilaku kerja wartawan selalu dibingkai dalam dua dimensi yang saling mempengaruhi, yakni dimensi teknik dan dimensi etik. Bagi pekerja jurnalistik, kedua dimensi ini mesti melekat dalam kinerja profesional mereka.

Keragaman isi siaran radio sejalan dengan filosofi media penyiaran yang mesti mampu mengkonkretkan kepentingan publik yang sukar ditangkap (Kellner, 1990: 185). Dominasi penyiaran 
swasta yang ada sekarang ini belum merepresentasikan kepentingan publik yang tersekat-sekat dalam pelbagai komunitas. Padahal, secara normatif keberadaan media apapun mestinya disandarkan pada nilai-nilai mendasar pada publik dalam berkomunikasi. McQuail (dalam Curran dan Gurevitch, 1991: 72) merekomendasikan nilai-nilai dasar komunikasi dalam asas kebebasan, keadilan, dan ketenteraman atau ketertiban. Persoalan diversity menjadi mutlak diperlukan dalam ketiga nilai tersebut. Secara sosial, warga berhak atas perasaan solidaritas yang tinggi serta persamaan kontrol dan keterlibatan kontrol atas media. Di sisi lain, warga berhak atas otonomi dan otentisitas muatan medianya. Oleh karenanya, konsep media publik lahir dari semangat untuk mewujudkan ketiga nilai tersebut dalam kehidupan bermedia kita.

Dalam bahasa Pulitzer, pers hadir untuk menjaga keselamatan dan kesejahteraan masyarakat (Hohenberg, 1978: 9). Insan pers pada lembaga media bukan hanya bekerja untuk sekadar mencari dan mengkomunikasikan berita maupun opini, namun mereka juga mempunyai tanggung jawab sosial untuk melihat kebenaran dari apa yang ditulis dan disampaikannya. Kepercayaan seperti ini muncul dalam sistem pers yang menganut paham tanggung jawab sosial. Muncul sejak permulaan abad kedua puluh ini merupakan reaksi keras terhadap paham kebebasan mutlak dari teori pers libertarian. Landasan ideal dari teori ini adalah bahwa kebebasan pers harus disertai tanggung jawab kepada masyarakat.

Dalam perspektif tanggung jawab sosial, pers memiliki tanggung jawab kepada masyarakat untuk melaksanakan tugas-tugas pokok yang dibebankan mereka yakni menjadi media komunikasi umum dalam masyarakat moderen. Kebebasan pers sendiri masih dipertahankan dengan penambahan tugas dan beban bahwa kebebasan yang mereka miliki harus disertai dengan kewajibankewajiban untuk bertanggung jawab. Berbeda halnya dengan perspektif liberal yang menempatkan pers secara bebas, perspektif tanggung jawab sosial cenderung mengedepankan kepentingan umum. Tugas pers harus dapat dipertanggungjawabkan kepada masyarakat. Dalam perspektif tanggung jawab sosial, pers mempunyai sejumlah fungsi spesifik, yakni: (1) melayani sistem politik dengan penyajian informasi, diskusi, dan perdebatan terhadap peristiwa-peristiwa yang terjadi di masyarakat; (2) memberi penerangan kepada masyarakat sehingga mereka mampu mengatur diri sendiri; (3) melindungi hak-hak individu dari campur tangan pemerintah dengan berlaku sebagai "anjing penjaga" (watch dog); (4) melayani sistem ekonomi, terutama dalam mempertemukan penjual dan pembeli melalui media iklan; (5) memberi hiburan dan (6) mengatur keuangan sendiri agar mampu membiayai keperluan sendiri sehingga dapat bebas dari tekanantekanan kelompok kepentingan khusus (Rachmadi (1990: 4).

Sebagai institusi jurnalistik berlabel lembaga penyiaran publik, RRI dituntut mampu melayani kebutuhan informasi dan hiburan berbagai lapisan masyarakat tanpa kecuali. Namun berbeda halnya dengan institusi pers pada umumnya, terdapat adanya Program siaran berita RRI harus mempunyai nilai edukatif, membangun rasa kebangsaan, dan menjaga nilai-nilai kearifan masyarakat. Untuk itu, diperlukan tidak hanya dana yang besar, tapi juga sumber daya manusia dan infrastruktur yang mendukung. Tanpa itu, misi RRI sebagai lembaga penyiaran publik tidak akan terwujud. Setidaknya ada lima prinsip yang harus ditaati sebagai sebuah lembaga penyiaran publik. Pertama, radio publik 
harus tersedia bagi seluruh masyarakat. Kedua, radio publik harus merefleksikan selera dan minat masyarakat. Ketiga, radio publik harus ditujukan untuk semua warga negara secara independen terlepas dari posisi sosial, politik maupun agama mereka. Keempat, lembaga siaran publik harus mempunyai komitmen pendidikan masyarakat. Kelima, lembaga siaran publik harus dilepaskan dari kepentingan pribadi (vested interest).

Mempertimbangkan RRI di daerah sebagai institusi pers lokal, adalah menarik untuk melihat hubungannya dengan masyarakat setempat karena jalinan yang terhubung melalui siarannya selanjutnya akan melahirkan kebergantungan. Maka, asas kepatutan yang senantiasa harus dijaga di dalam praktikm jurnalistik radio adalah sikap independen (mandiri) dan harus tetap melakukan fungsinya dalam lingkungan kompetensi profesional. Radio, sebagai pemberita perlu berusaha melindungi atau memperbesar lingkup otonominya dalam kaitannya dengan sumber akhir kekuasaan di tingkat lokal. Selaras dengan pendapat McQuail (1987: 276) tentang prinsip-prinsip pemberitaan dalam kinerja jurnalisme, dalam konteks ini radio selaku lembaga pers perlu senantiasa mengembangkan sikap obyektif, terbuka, netral, dan menyeimbangkan sehingga menciptakan jarak dari kekuasaan tanpa menimbulkan konflik.

Dalam analogi yang dikembangkan Mursito (2009), agenda media dalam jurnalisme publik tidaklah ditentukan oleh para elit, melainkan ditentukan oleh media berdasarkan urusan publik (public affair). Pada aras ini, media akan memperlihatkan aktualisasinya sebagai kekuatan keempat, yang berdaya guna mengembangkan iklim diskusi publik yang dapt dimulai dengan penyediaan ruang publik di media itu sendiri. Pada aras manejemen penyiaran berita radio.
Caranya dapat dimulai melalui kebijakan redaksional, dimana rubrik atau topik yang yang berhubungan dengan akses publik diperluas, sehingga aspirasi nyata publik akan lebih dominan daripada aspirasi elit. Dengan kata lain, institusi pers radio yang membantu menciptakan publikisasi ruang-ruang kepentingan bagi seluruh kelompok masyarakat. Idealisme ini dapat terwujud apabila tercapai pra kondisi yang memungkinkan, yakni iklim kelembagaan yang inklusif, egaliter, dan bebas tekanan.

Sebagai perwujudan dari fungsi media massa, yakni menjadi perekat sosial, pengawasan sosial, pendidikan, dan menghibur. Setiap radio siaran dalam menyusun programnya selalu membagi ke dalam beberapa kategori atau golongan siaran. Berdasarkan standar UNESCO misalnya, penggolongan acara siaran terbagi dalam lima kelompok meliputi: siaran berita dan informasi, siaran pendidikan, siaran kebudayaan, siaran hiburan, dan siaran lain-lain atau siaran penunjang. Akan halnya yang terkait dengan sisi jurnalistiknya, pada prinsipnya tidak ada perbedaan mendasar antara produk karya jurnalistik radio dengan media lain semacam majalah atau surat kabar. Perbedaan yang ada hanya dari segi teknis publikasinya saja, di mana produk karya jurnalistik radio bersifat auditif. Sebuah laporan peliputan ditulis dan dibacakan oleh penyiar atau pembawa acara. Di sisi lain, model peliputan langsung radio justru memiliki keunggulan tersendiri karena dapat secara langsung didengar oleh khalayak dengan kemungkinan daya jangkau yang lebih luas dibandingkan media cetak.

$$
\text { Secara umum, penayangan }
$$
program-program berita di RRI melekat atau membersamai paket penayangan program siaran lain (hiburan dan pendidikan). Karenanya, siaran pemberitaan hadir dalam konsepsi produksi program yang memungkin- 
kannya diminati pendengar. Secara konsepsional, terdapat delapan syarat agar program acara siaran radio memperoleh perhatian. Kedelapan syarat tersebut meliputi: (1) kesesuaian sasaran siaran dengan pendengarnya, (2) spesifikasi materi program, (3) keutuhan program siaran, (4) format kemasan program, (5) penempatan waktu siar, (6) orisinalitas acara, (7) kualitas siaran, dan (8) kesederhanaan penggunaan bahasa. Dengan melihat kedelapan hal-hal pokok di atas, menjadi jelas betapa banyak hal yang harus diperhatikan dalam merancang sebuah program acara, termasuk di dalamnya siaran yang terkategori sebagai program informasi jurnalistik.

Dalam konsepsi manajemen media penyiaran, untuk mengembangkan konten-konten siaran jurnalistik yang berkualitas diperlukan sejumlah kesiapan mulai dari kelengkapan peralatan teknis, finansial, kemampuan dan kecukupan sumber daya pendukung, akses terhadap sumber-sumber informasi, dan manajemen redaksional. Dalam taraf inilah, pemetaan terhadap problematika praksis jurnalistik di lingkungan RRI dilakukan. Terdapat empat stasiun yang dikaji, meliputi stasiun Gorontalo, Manokwari, Batam, dan Makassar. Keempat stasiun tersebut merupakan sebagian dari belasan stasiun lain yang pernah dijadikan sebagai pilot projek pemetaan potensi pengembangan Direktorat Program dan Produksi LPP RRI pada rentang tahin 2011 sampai dengan tahun 2012. Penggalian data dilakukan melalui observasi lapangan, uji petik terhadap dokumentasi yang ada, serta wawancara atau FGD terhadap sejumlah informan atau narasumber.

\section{Problematikan Pengembangan Program Siaran Jurnalistik RRI \\ Merangkum berbagai kondisi yang beragam antara stasiun RRI satu dengan}

yang lain, bagian ini akan mencoba terlebih dahulu memetakan temuantemuan umum yang mendasari problematika umum yang dihadapi dalam siaran RRI khususnya siaran Pro1, Pro2, Pro4 dan siaran perbatasan. Beberapa isu yang mengemuka antara lain; pertama, rendahnya tingkat kependengaran radio dan jangkauan RRI di masing-masing wilayah. Waktu utama mendengarkan radio masyarakat setempat umumnya berkisar pada saat pagi menjelang beraktivitas, sore hari selepas aktivitas, dan malam hari sebagai teman istirahat malam. Masyarakat setempat umumnya cenderung meminati siaran-siaran radio swasta yang memang atraktif dan cepat menyesuaikan diri dengan perkembangan selera pendengar, atau justru sebaliknya, mampu menciptakan selera pendengarnya. Kependengaran siaran RRI umumnya banyak pada Pro1, yang secara teknis mampu menjangkau seluruh wilayah yang ditelaah. Di kalangan dan di kalangan generasi muda, kependengaran siaran RRI juga dominan pada siaran Pro2. Pada stasiun yang menyiarkan siaran Pro4 (Makassar, Manokwari), siaran Pro4 harus diakui belum menjadi kanal pilihan. Kurangnya minat mendengarkan siaran Pro4 ini diperumit pula oleh lemahnya jangkauan pemancar di kawasan kota. Sebagai contoh, coverage siaran Pro4 dominan di kawasan pinggiran alias lebih banyak menjangkau kawasan luar kota Makassar. Kawasan dalam kota yang secara umum menjadi arena sasaran strategis siaran justru luput dari jangkauan RRI Pro4.

Kedua, pada aras internal kinerja RRI, terdapat hambatan-hambatan teknis dan manajerial RRI untuk dapat bersaing dengan radio-radio lain di masing-masing daerah. Secara teknis, permasalahan tersebut diakibatkan oleh rendahnya kualitas audio yang dihasilkan oleh siaran RRI. Pada siaran Pro2 misalnya, sedikitnya area di kawasan kota yang 
d'apat menerima siaran dengan baik menjadi kendala teknis sehingga pendengar beralih ke radio lain. Oleh karena itu, diperlukan evaluasi teknis serta penataan peralatan siaran (pemancar dan peralatan siaran) agar setidaknya kawasan sasaran siar dapat terjangkau secara utuh. Sedangkan hambatan manajerial pengembangan siaran berkutat pada isu positioning, sumber daya manusia, dan pemrograman siaran itu sendiri. Hambatan manajerial ini dimungkinkan oleh budaya organisasi yang kurang luwes menghadapi dinamika perubahan eksternal, baik dari sisi persaingan radio maupun kegamangan dalam memposisikan diri sebagai radio publik dan bukan radio pemerintah.

Kurang luwesnya menghadapi dinamika eksternal ini secara sederhana terlihat dari pemosisian RRI di lingkungan internal RRI yang belum menjadi prioritas. Struktur kelembagaan pada divisi masing-masing programa siaran yang seharusnya memiliki elemenelemen utama penyangga fungsi informasi, hiburan maupun pendidikan tidak tergambar secara utuh. Tidak efektifnya fungsi-fungsi kepengarahan, pemandu kreatif siaran, serta kurangnya jurnalis berkelindan dengan problem penganggaran yang dinilai terlampau kecil untuk menjangkau fungsi-fungsi tersebut. Secara tersirat ini menggambarkan bahwa pengelolaan siaran RRI belum mengoptimalkan sistem manajemen mutu siaran yang memadukan sistem perencanaan, pengorganisasian, pengarahan, pelaksanaan, dan evaluasi secara menyeluruh dan berkelanjutan. Lemahnya sistem dokumentasi siaran sebagai bagian terakhir mata rantai manajemen mutu siaran menggambarkan budaya organisasi RRI belum dikembangkan secara serius.

\section{Daftar Pustaka}

Mursito : "Visi Jurnalisme Publik dalam Demokratisasi Politik, Jurnal Komunikasi Massa UNS Volume 2 No 2, Januari 2009.

Adiputra, Wisnu Martha. 2006. Menyoal Komunikasi Memberdayakan Masyarakat. Yogyakarta: Penerbit FISIPOL UGM

Hohenberg, John. 1978. The Professional Journalist ( $4^{\text {th }}$ Ed.), New York: Holt, Rinehart \& Winston.

Kellner, Douglas. 1990. Television and The Crisis of Democracy. Boulder: Westview Press.
McChesney, Robert W. 2004. The Problem of Media. New York: Monthly Review.

McQuail, Denis. 1987. Mass Communication Theory (2end edition). Erlangga: Jakarta

Rachmadi, F. 1990. Perbandingan Sistem Pers, Jakarta: Gramedia.

Siregar, Ashadi. "Etika Komunikasi", Laporan Penelitian Jurusan Ilmu Komunikasi FISIPOL UGM, 1993.. 
Jumal komunikasi, Volume 10, Nomor 1, Oktober 2015 